\title{
Human Rights and Legal Protection of Persons with Disabilities in Aviation Industry in Indonesia
}

\author{
Adya Paramita Prabandari ${ }^{1}$, Elfia Farida ${ }^{1}$, Rahayu ${ }^{1}$ \\ ${ }^{1}$ Lecturer at Diponegoro University, Indonesia
}

\begin{abstract}
Various matters relating to persons with disabilities are often overlooked and often lead to discrimination against them in various fields of life. Likewise, in Indonesia there is often discrimination against persons with disabilities in various aspects of life, including in aviation. For this reason, it is very important to analyze the protection of the rights of persons with disabilities in Indonesian aviation. The method used is a normative juridical method using a statute approach and conceptual approach to analyze secondary data obtained through library research. The government as a duty bearer is fully responsible for ensuring good and accessible service quality and providing facilities for persons with disabilities in flight. Likewise, airport and airline operators as air transport service providers should have SOPs of services that are in accordance with Government policy in order to provide maximum and equal services for persons with disabilities, as a form of protection for the rights possessed by persons with disabilities.
\end{abstract}

Keywords: Protection, rights of disabilities, aviation, Indonesia.

\section{Introduction}

Globalization is a very rapid and fundamental change in the structure of human life that has occurred since the beginning of the 21 st century, and brings enormous changes in various fields, including the field of transportation. The development of transportation technology is very rapid, where the current movement of people, capital, and goods, both between countries and between regions in various parts of the world takes place more quickly with the support of aircraft transportation modes. Modes of aircraft transportation are not only used by people with normal conditions, but are also carried out by people who have different abilities and conditions from normal and reasonable of people with disabilities. In Indonesia, problems relating to persons with disabilities are often ignored and often lead to discrimination against them in various fields of life.

\section{Corresponding Author:}

\section{Adya Paramita Prabandari}

Lecturer at Faculty of Law, Diponegoro University, Jl. Prof. Soedarto, Tembalang, Semarang, Central Java50275, Indonesia e-mail: adyapprabandari@gmail.com
Likewise in civil aviation, where there are several times discrimination against persons with disabilities carried out by airlines, even the case reaches the legal domain ${ }^{1}$.

In aviation industry, there are some incidences discriminating persons with disabilities in flight, although WHO has stated that disability is a human condition, and is not a type/form of disease ${ }^{2}$. In addition, another form of discrimination carried out by airlines against persons with disabilities is the obligation to bring a companion for persons with visual impairments and other persons with disabilities, due to the notion that aircraft are not directly accessible for people with mobility disabilities ${ }^{3}$. Persons with disabilities, as members of the community and Indonesian citizens, truly have the same position, rights and obligations as other Indonesian citizens, although it cannot be denied that persons with disabilities have physical and/or mental disorders that can interfere or constitute obstacles to carrying out activities like people without disabilities. This paper explores the protection of persons with disabilities in Indonesian aviation by using human rights perspective.

\section{Research Method}

The research method used in this paper is a normative juridical method $^{4}$, using a statute approach and 
conceptual approach ${ }^{5}$. The data used are secondary data obtained through library research. The data is processed and analyzed using qualitative analysis method and then presented in the form of systematic writing.

The Perspectives of Human Rights of People with Disabilities: Article 1 of the Convention on the Rights of Persons with Disabilites describes that persons with disabilities include those who have long-term physical, mental, intellectual or sensory impairments which in interaction with various barriers may hinder their full and effective participation in society on an equal basis with others. Meanwhile, according to the International Classification of Functioning, Disability, and Health, disability is defined as problems in the body function or structure such as a significant deviation or loss, a reduction, an increase, or an excess ${ }^{6}$. People with disabilities can be classified some, which are mobility and physical impairments, spinal cord disability, acquired brain injury, vision disability, hearing disability, cognitive or learning disabilities, psychological disorders and invisible disabilities.

Human rights are rights possessed by humans, solely because he is human. Humans have human rights not because they are given to them by the community or based on positive law, but merely based on their dignity as human beings ${ }^{7,8}$. Human rights are fundamental rights in human beings. The institutionalization of human rights began with the enactment of various human rights instruments in various countries in the form of laws and declarative instruments containing provisions on human rights, including: Bill of Rights) in England in 1688; Declaration of Independence in 1776; and Declaration des Droits de l'homme et du Citoyen in France in $1789^{9}$. These instruments are the starting point for the discussion of human rights instruments so that they finally produce the Universal Declaration of Human Rights (UDHR) which is a document of international recognition of human rights prepared by the UN Human Rights Commission. This declaration was accepted by United Nations General Assembly Resolution Number: 217A (III) on 10 December 1948.

In the First Paragraph of the Opening of the UDHR it was stated that while recognition of the inherent dignity and of the equal and inalienable rights of all members of the human family is the foundation of freedom, justice and peace in the world. This is an affirmation that human rights are the basis of freedom, justice and peace in the world. Furthermore, Article 3 of the UDHR states that everyone has the right to life, liberty and security of person. The human rights inherent in every human being affirmed in Article 3 of the UDHR are of course also inherent in persons with disabilities. As part of humanity and having the same human rights as other people who do not have barriers and disabilities, an important milestone in the recognition, respect and protection of human rights is the ratification of the Convention on the Rights of Persons with Disabilities (CRPD) on December 13 2006 in the 61st Session of the UN General Assembly with resolution A/RES/61/106. This convention came into force on May 3, 2008. CRPD is a convention based on the concept of modern equality that has developed in various phases of equality law with different ideas of equality ${ }^{10}$.

The purpose of CRPD is to promote, protect, and ensure the full and equal enjoyment of all human rights and fundamental freedoms by all persons with disabilities, and to promote respect for their inherent dignity. States are required to report regularly about the implementation of the rights of disabled people to enable the Committee to monitor the implementation of the Convention from time to time ${ }^{11}$. For this reason, the States Parties to this convention have obligations which include guarantee and promote the full realization of all human rights and fundamental freedoms for all persons with disabilities without discrimination in any form that is based on disability; prohibit all discrimination based on disability and ensure equal and effective legal protection for persons with disabilities against discrimination based on any reason; adopt policies that are immediate, effective, and appropriate to increase awareness of the whole community, including at the family level, regarding persons with disabilities, and to maintain respect for the rights and dignity of persons with disabilities; and to combat stereotypes, prejudices, and harmful practices concerning persons with disabilities, including those based on gender and age, in all aspects of life; take appropriate policies to ensure access for persons with disabilities, on an equal basis with others, to the physical environment, transportation of information and communication, including information and communication technology and systems, and to other facilities and services that are open or available to the public, both in urban and rural areas.

Legal Protection of Persons with Disabilities in Indonesian Regulations: In human rights law, the State or Government has a duty bearer covering 3 (three) obligations, that are obligation to respect, obligation 
to fulfill and obligation to Protect ${ }^{9}$. With regard to human rights owned by persons with disabilities and the Government of Indonesia as a duty bearer, the Government of Indonesia on February 28, 1997 has enacted Law No. 4 of 1997 concerning Disabled Persons, which among others regulates the rights and obligations of persons with disabilities, equality of opportunities owned by persons with disabilities in every aspect of life, as well as criminal provisions for offenders and administrative sanctions.

Along with the development of the times and the evolution of thought in society, especially in medicine, in the international world the term and concept of impairment, then changed to disability, which is considered more complex and comprehensive than impairment ${ }^{12}$. Furthermore, impairment is instead a component of disability, in the Disability Component Categorization such as impairment, limited activity and participation, individual characteristics and environment and individual effects ${ }^{13,12}$. Impairment is only one component of the four categories of disability components. In this case, the social environment is also a component that plays a role in creating social and cultural barriers for persons with disabilities to be able to live equally as members of the community. The community also has the responsibility to remove these barriers so that the mobility of persons with disabilities becomes more spacious and more free to be able to access and utilize the potential resources around them for the development of their potential to be able to realize their independence.

Changes in the mindset and concept of impairment to use the term "disability" in the international community inevitably lead to changes in the policy orientation of the Government of Indonesia. This was proven by the participation of Indonesia as one of the signatory States that signed the Convention on the Rights of Persons with Disabilities on March 30, 2007, and then ratified it with Law Number 19 of 2011 concerning Ratification of the Convention on the Rights of Persons with Disabilities which took effect on November 10, 2011. This was followed by the enactment of Law No. 8 of 2016 concerning Disabled Persons, which replaced Law No. 4 of 1997 concerning Disabled People because it no longer complies with the paradigm of the needs of persons with disabilities. In addition, the Government also includes elements of protection for persons with disabilities in various laws and regulations in Indonesia, including those relating to aviation.
In various laws and regulations regarding aviation and air transportation, the Government of Indonesia has included rules regarding services and handling for persons with disabilities. First, Law No. 1 of 2009 concerning Aviation stated that the holder of a commercial air transportation business permit is obliged to serve prospective passengers fairly without discrimination on the basis of ethnicity, religion, race, class, and economic and social status. This article regulates the right of persons with disabilities to receive services in the form of special treatment and facilities from commercial air transport businesses. Services in the form of special treatment and facilities include at least to provide priority to additional seats; provision of facilities for boarding and alighting from aircraft and facilities while in the aircraft; the availability of personnel who can communicate with people with disabilities; and the availability of manuals on flight safety and security for aircraft passengers and other facilities that can be understood by persons with disabilities. Additional treatment and facilities are free of charge. Services in the form of special treatment and facilities for passengers with disabilities or sick people are intended so that they can also enjoy proper transportation services. Moreover, Article 239 stipulates that persons with disabilities are entitled to receive services in the form of special treatment and facilities from an airport business entity or airport operating unit.

Second, the protection is specified in Minister of Transportation Regulation No. PM 98 of 2017 concerning Accessibility for Persons with Disabilities and Sick People in Transportation Facilities and Infrastructure. The Regulation regulates that public transportation service providers are required to provide accessible service facilities and infrastructure for service users with special needs such as assistive devices to move up and down from and to transportation facilities, audio/visual information about travel that is easily accessible, priority seating and easily accessible toilets, and the provision of specific signs or instructions in the service area at the means of transportation. Transportation service providers are also required to provide information centers and personnel equipped with relevant training in order to help service users with special needs. Minister of Transportation Regulation No. 38 of 2015 concerning Domestic Air Transport Passenger Service Standards regulates to persons with disabilities that passengers with special needs are passengers because of their physical condition and/or special requests for 
passengers who need special facilities and treatment, such as persons with disabilities, elderly people, children, pregnant women and sick people. The air transport service providers in providing services for air transport passengers must have a reference in the form of air transport passenger service standards. The service standard starts at the time of entering the airport gate until the passenger exits from the airport gate after the flight. Domestic air passenger service standards at airports must contain the following components: safety services; security services; reliability service; comfort service; convenience services; and equality services. Even indicators and benchmarks for the fulfillment of the equality service components have been provided in Attachment I to this Ministerial Regulation. The service standards for domestic air transport passengers while on board aircraft that contain the same components as the domestic air passenger service standard components at airports. The air transport passenger service provider is required to prepare a standard service document in accordance with the specified components, and the document must be approved by the Director General of Civil Aviation.

In addition, Minister of Transportation Regulation No. 77 of 2015 concerning Airport Facility Standardization and Certification regarding passengers with special needs regulated in Article 9, stated that airport facilities for passengers with special needs must be able to provide services to passengers with special needs with or without the help of others, safely and comfortably. However, there is still a variety of discrimination against persons with disabilities in Indonesian civil aviation and other public sectors. ${ }^{14,15}$ This is often caused by a lack of socialization and information received and understood, both by airport officials and airline staff (ground-staff and cabin crew), regarding the rules of non-discriminatory service standards for persons with disabilities, both rules in statutory regulations which are government policies, as well as airline service standards issued by each airline as an air transport business entity.

\section{Conclusion}

The Indonesian Constitution provides for the recognition, guarantees and protection of the human rights of all its citizens, including persons with disabilities who are also human beings who have fundamental and human rights like other humans in general who are inherent from their birth and cannot be taken away or violated by anyone. Therefore, the Government of Indonesia as a duty bearer has the obligation and responsibility to fulfill the human rights inherent in persons with disabilities. Various government policies, especially in the field of aviation, have also accommodated and provided special rules regarding matters relating to persons with disabilities. For example, standardization of services and treatment of persons with disabilities. However, in practice it cannot be denied that there are still many violations and discrimination against people with disabilities. Existing regulations are still not very well known to all airport operators and air transport business entities (airlines), so they have not been able to apply effectively in practice. Therefore, the government should be the duty bearer who is authorized to issue regulations, fully responsible for ensuring good and accessible service quality and providing facilities for persons with disabilities. Likewise, airport and airline operators as air transport service providers should have SOPs of services that are in accordance with Government policies in order to provide maximum and equal services for persons with disabilities, as a form of protection for the rights possessed by persons with disabilities.

Ethical Clearance: This research was ethically approved by Faculty of Law, Universitas Diponegoro, Semarang, Indonesia

Funding: The research was financially funded by Faculty of Law, Diponegoro University from the 2020 fiscal year.

Conflict of Interests: There are no conflict of interests.

\section{References}

1. Prabandari AP, Susetyorini P, Hartono D. The urgency of ratification of the 2010 Beijing convention concerning enforcement of unlawful acts against international civil aviation. Academic Journal of Interdisciplinary Studies. 2020;9(2): 31-35.

2. World Health Organization. World report on disability 2011. WHO;2011.

3. Darcy S. (Dis) embodied air travel experiences: Disability, discrimination and the effect of a discontinuous air travel chain. Journal of Hospitality and Tourism Management. 2012;19:50.

4. SoemitroRH. Legal research methodology and jurimetry. Ghalia Indonesia;1990.. 
5. Ibrahim J. Theory and methodology of normative legal research. Bayumedia;2006.

6. Silva TN, Guarda JB, Silva LL, Figueiredo JP, Menegon NL. Passengers with disabilities in the Brazilian air transport: different actors and similar perspectives. Gestão \& Produção. 2017 Apr;24(1):136-47.

7. Donnely J.Universal human rights. Theory and Practice; 2003.

8. Smith RK, Asplund KD, Marzuki S. Human rights law. Center for the Study of Human Rights, UII;2008.

9. Rahayu. Human Rights Law. Semarang: Diponegoro University Press;2015.

10. Degener T. Disability in a human rights context. Laws. 2016;5(3):35.

11. Chouinard V. Living on the global peripheries of law: Disability human rights law in principle and in practice in the global south. Laws. 2018;7(1):8.

12. Prasetyo FA. Disability and health issues: between the evolution of concepts, human rights, complexity of problems, and challenges. Jakarta: Ministry of Health; 2014.

13. Dempsey IJ, Nankervis K. Community disability services: An evidence-based approach to practice. Purdue University Press;2006.

14. Silalahi W, Hamzah G, Saraswati R, Tyesta L. Controversy of the capability of voters with mental health disorder in the general election. MedicoLegal Update. 2020;20(2):703-707

15. Utami NS, Prasetyoningsih N, Hidayat A, (...), Saraswati R, Budiono A. Equality of the political rights of people with mental disorders (PWMD) in general elections. Indian Journal of Forensic Medicine and Toxicology. 2019;13(4):1571-1575. 